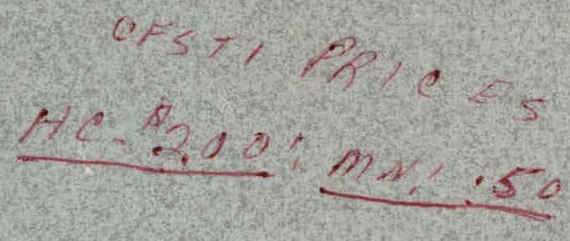

\title{
ELK RIVER REACTOR OPERATIONS ANALYSIS PROGRAM. TOPICAL REPORT SPENT FUEL SHIPPING CASK CRITICALITY ANALYSIS: \\ TASK 617
}

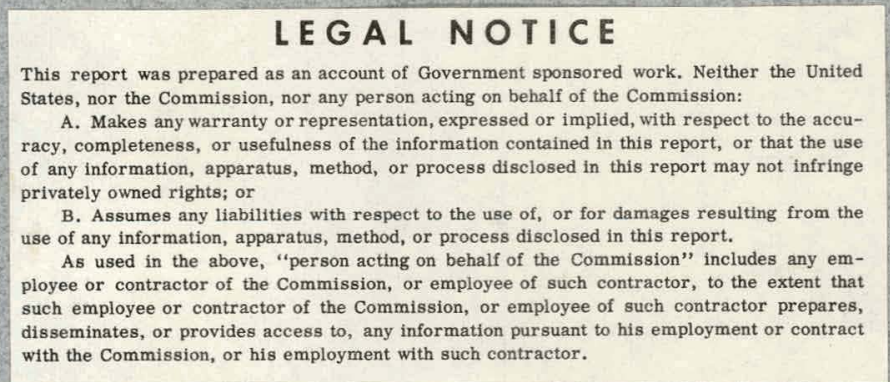

Prepared for

Chicago Operations Office

U. S. Atomic Energy Commission under

Project Agreement No. 1

to

Contract AT $(11-1)-1357$

July 1966

by

E. D. Kendrick, Jr.

ALLIS-CHALMERS

Atomic Energy Division

6935 Arlington Road

Bethesda, Maryland 20014 


\section{DISCLAIMER}

This report was prepared as an account of work sponsored by an agency of the United States Government. Neither the United States Government nor any agency Thereof, nor any of their employees, makes any warranty, express or implied, or assumes any legal liability or responsibility for the accuracy, completeness, or usefulness of any information, apparatus, product, or process disclosed, or represents that its use would not infringe privately owned rights. Reference herein to any specific commercial product, process, or service by trade name, trademark, manufacturer, or otherwise does not necessarily constitute or imply its endorsement, recommendation, or favoring by the United States Government or any agency thereof. The views and opinions of authors expressed herein do not necessarily state or reflect those of the United States Government or any agency thereof. 


\section{DISCLAIMER}

Portions of this document may be illegible in electronic image products. Images are produced from the best available original document. 


\section{AEC LEGAL NOTICE}

This report was prepared as an account of Government sponsored work. Neither the United States, nor the Commission, nor any person acting on behalf of the Commission:

A. Makes any warranty or representation, expressed or implied, with respect to the accuracy, completeness, or usefulness of the information contained in this report, or that the use of any information, apparatus, method, or process disclosed in this report may not infringe privately owned rights; or

B. Assumes any liabilities with respect to the use of, or for damages resulting from the use of, any information, apparatus, method or process disclosed in this report.

As used in the above, "person acting on behalf of the Commission" includes any employee or contractor of the Commission, or employee of such contractor, to the extent that such employee or contractor of the Commission, or employee of such contractor, prepares, disseminates, or provides access to any information pursuant to his employment or contract with the Commission, or his employment with such contractor. 


\begin{abstract}
Results are presented of criticality calculations for the Elk River Reactor 28-element spent fuel shipping cask. The addition of one weight percent of cadmium to the aluminum used in fabrication of the 28-element fuel basket is determined to be sufficient to preclude criticality. Assumptions used in the study are conservative and the results show that the requirements of 10 CFR 71 will be met for any combination of fuel elements now available or presently contemplated for use in the ERR core.
\end{abstract}


Chicago Operations Office

U. S. Atomic Energy Commission

9800 South Cass Avenue

Argonne, Illinois

Attention: Mr.W. G. Albert, Reactor Engineer

20 copies

Division of Reactor Development

U. S. Atomic Energy Commission

Washington 25, D. C.

Attention: Mr. Donald Erb, Acting Chief

Water Reactors Branch

2 copies

Division of Technical Information Extension

Post Office Box 62

Oak Ridge, Tennessee

10 copies

(plus master)

Rural Cooperative Power Association

Elk River, Minnesota

Attention: Mr. E. J. Welsh, Manager

Nuclear Contract Department

6 copies

Knapp Mills Incorporated

Foot of West Street

Wilmington, Delaware

Attention: Mr. L. A. Schmidt, Contracts Administrator

2 copies 


\section{CONTENTS}

LIST OF TABLES ........................... vi

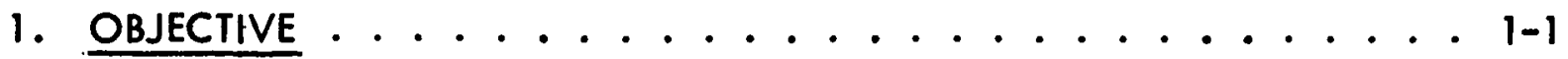

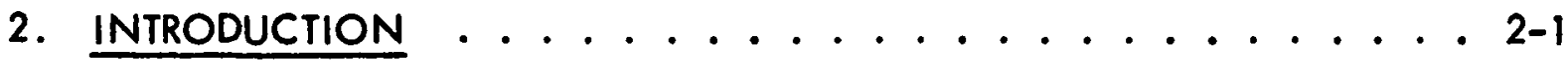

3. SUMMARY ...................... 3-1

4. METHOD OF ANALYSIS .................. . . . . .

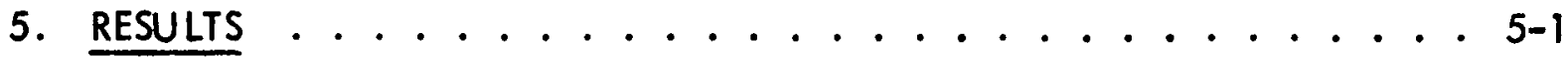

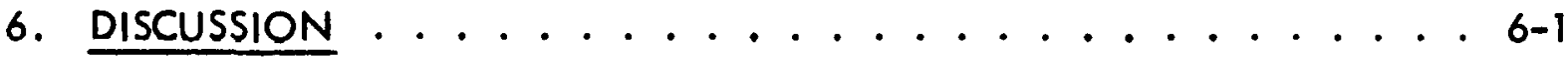

7. CONCLUSIONS .................... . . .

8. FIGURES ......................

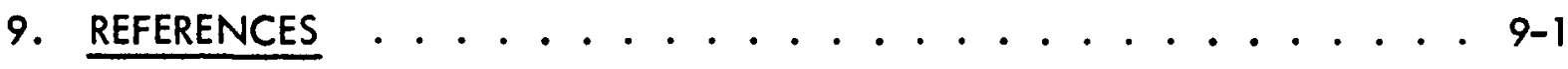




\section{TABLES}

4-1 Neutron Energy Groups ... . . . . . . . . . . 4-1

5-1 Multiplication Factor of Infinite Cask Array with No Cadmium in Fuel Basket ................... . . . 5-1

5-2 Infinite Multiplication Factor for Fuel Basket Assembly with No Cadmium in Fuel Basket . . . . . . . . . . . . 5-1

5-3 Multiplication Factor of Infinite Cask Array with 28 Elements, 5.2 wt.\% U-235 ................. . . 5-2

5-4 Infinite Multiplication Factor for Fuel Basket Containing 28 Elements,

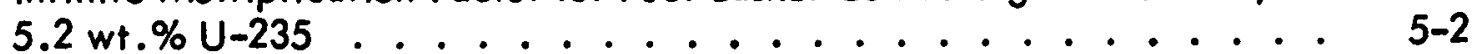




\section{OBJECTIVE}

The objective of this task was to determine the weight percentage of cadmium which must be added to the aluminum used in fabricating the fuel basket of the Elk River Reactor (ERR) 28-element spent fuel shipping cask to ensure that the cask meets the criticality requirements of 10 CFR 71 . 


\section{INTRODUCTION}

A 28-element fuel basket for the spent fuel shipping cask was designed by Knapp Mills, Inc., and is intended to be used for foreign and domestic shipments of spent fuel from the Elk River Reactor. The number of elements in the cask is large enough to present a criticality problem if one makes the usual conservative assumptions with regard to the reactivity of the fuel to be shipped. This problem was uncovered by a preliminary analysis $(1)$ which was performed to determine the keff of three different loadings of fresh fuel. A meeting was held at the Knapp Mills offices in Wilmington, Delaware on January 9, 1964 to discuss possible solutions to the problem. At that time, it was decided that the best solution from a fabrication standpoint would be to use a 1 percent (by weight) cadmium-aluminum alloy for the basket instead of aluminum containing no cadmium with separate poison inserts or sleeves. It was also recognized that a new criticality analysis would be required to confirm the adequacy of the approach from a physics standpoint.

Further work on the project was deferred, however, until it was established with more certainty that the 28-element shipping cask would be required. On April 20, 1966, the ERR-OAP project at Allis-Chalmers was directed to proceed with the criticality analysis of the cask. This report presents the results of the analysis made.

The currently proposed regulations of the Atomic Energy Commission covering the shipment of special nuclear material are contained in Part 71 of Title 10, Code of Federal Regulations (10 CFR 71) published December 21, 1965. These regulations define the conditions under which shipments of spent fuel elements must remain subcritical (i.e., multiplication factor $<1.0$ ). The two main requirements are that:

(1) an unlimited number of undamaged packages (casks) would be subcritical in any arrangement when mixed with any number of other similar packages, assuming optimum interspersed hydrogenous moderation between the packages; and

(2) two hundred fifty packages would be subcritical in any arrangement if each package were subjected to specified hypothetical accident conditions with close reflection by water on all sides of the array, and with optimum interspersed hydrogenous moderation.

In effect, then, an unlimited number of packages (shipping casks) must be considered and water moderation must be assumed to exist wherever it would increase the reactivity of the package. A drawing of the cask is shown in Fig. 1.

Unirradiated Core I fuel elements (see Fig. 2) contain fuel pellets which consist of a mixture of thoria $\left(\mathrm{ThO}_{2}\right)$ and fully enriched urania $\left(\mathrm{UO}_{2}\right)$. The fuel cladding is Type 304 stainless steel containing 600 ppm natural boron. Two types of fuel assemblies were used in the Core 1 loading: 
(1) spiked elements containing $5.2 \mathrm{wt} . \%$ of U-235 (metal basis)

(2) regular elements containing $4.3 \mathrm{wt} . \%$ of U-235 (metal basis)

Unirradiated Core II elements (see Fig. 3) are similar to the Core I elements except that the fuel cladding is Type 348 stainless steel containing no added boron; the pellets contain 4.4 wt. \% U-235 (metal basis).

The following conservative assumptions were used in the calculations:

(1) All fuel elements were assumed to be unirradiated even though actual discharge exposures will be on the order of $8,000 \mathrm{Mwd} / \mathrm{MT}$.

(2) All fuel elements were assumed to have no boron in the cladding.

(3) In the final analysis, all fuel elements were assumed to contain $5.2 \mathrm{wt} . \%$ U-235 (metal basis) with no boron in the clad even though there are only 22 Core 1 spiked elements; these had $600 \mathrm{ppm}$ boron in the cladding prior to irradiation.

To meet the requirements of 10 CFR 71 , all calculations were made for an infinite array of shipping casks; and water was assumed to be present in the fuel element cavities of the fuel basket and between the casks. 


\section{SUMMARY}

Criticality calculations were performed which considered the effect of various element types and of various amounts of cadmium added to the 28-element fuel basket on the multiplication factor of an infinite cask array. It was determined that the addition of 1.0 wt. $\%$ cadmium to the aluminum used in fabricating the fuel basket is sufficient to reduce the multiplication factor to less than 0.80 with even the most conservative assumptions regarding the reactivity of the fuel.

The criticality calculations also evaluated the multiplication factor of an infinite array of fuel baskets (without the cask portion). In this case, the results showed that the addition of $1.0 \mathrm{wt} . \%$ cadmium is sufficient to reduce the multiplication factor to less than 0.85 with the same conservative assumptions regarding the reactivity of the fuel.

It is concluded that $1.0 \mathrm{wt} . \%$ cadmium uniformly dispersed in the 28-element fuel basket is entirely sufficient to meet the criticality requirements of 10 CFR 71 for any combination of fuel elements now available and for any fuel presently envisioned for future use in the Elk River Reactor core. 


\section{METHOD OF ANALYSIS}

The Elk River 28-element spent fuel shipping cask assembly consists of the present ERRPNPF outer cask itself, (2) including the biological shielding and its associated structure, and the inner fuel basket. (3) The fuel basket is in the form of a cylindrical casting with 28 individually machined cavities for fuel elements. This casting is composed of Type 6061 aluminum containing a uniform dispersion of cadmium.

The Elk River fuel elements which will be available for future shipments are of the following types:

(1) Core 1 type elements with $600 \mathrm{ppm}$ natural boron in the cladding: these include 148 regular elements containing 4.3 wt.\% U-235 (metal basis) and 22 spiked elements of 5.2 wt.\% U-235 (metal basis); and

(2) Core II type elements with no boron in the clad: there are 150 elements of 4.4 wt. \% U-235 (metal basis).

As mentioned in Sec. 2, no credit was taken for the boron in the cladding and all calculations assumed fresh, unirradiated fuel. As a further conservatism, the final criticality analysis was based on 28 elements containing 5.2 wt. \% U-235 (metal basis).

The calculational methods which were used in the criticality analysis of the shipping cask have been proved and tested against experiment in the models that have been used for the Elk River Reactor. A short description of the nuclear and spatial models that were used is given in the following discussion.

The preliminary criticality analysis (1) of the 28-element shipping cask used a modified two neutron-energy group model. In this model, all absorptions and fissions were accounted for as effective one-group cross sections based on a Westcott-type spectrum. $(4,5)$ This model had been normalized to predict the excess reactivity of the Elk River core as determined during the critical experiments.

The final criticality analysis (which is the subject of this report) was performed using three neutron-energy groups. The energy ranges of these groups are given in Table 4-1.

TABLE 4-1

\section{NEUTRON ENERGY GROUPS}

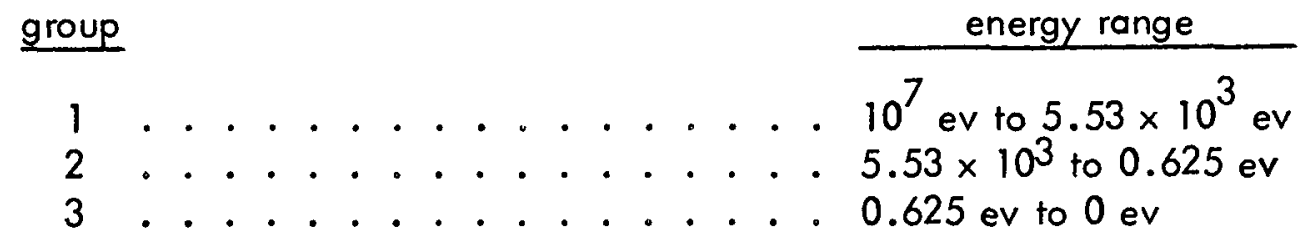


Slowing-down spectra (above $0.625 \mathrm{ev}$ ) were generated for the shipping cask materials by the GAM-1 code. (6) The diffusion parameters for the two upper energy groups were then averaged over these spectra. The thermal spectra (below $0.625 \mathrm{ev}$ ) were calculated by the TEMPEST-II code $(7)$ and the thermal diffusion parameters were averaged directly over these spectra except in the case of the fuel element regions. Since a fuel element assembly consisting of fuel, cladding and moderator materials is necessarily treated as a homogenized region in all two-dimensional diffusion calculations, the necessary parameters were developed in the following manner. To account for the actual intracell flux distribution through the fuel, cladding and moderator, multi-energy thermal group parameters for the individual materials were used in one-dimensional multigroup transport calculations. The calculations yielded multigroup intracell flux distributions which, in combination with the multi-energy thermal parameters for each material, were used to derive space-and energy-averaged parameters for a homogenized fuel element region over a single thermal group.

The above calculations give the three-group diffusion parameters for the shipping cask materials which are necessary for the spatial calculations described below.

The spatial model that has been used in the criticality analysis of the 28-element shipping cask consists of a detailed two-dimensional mockup of the components of the cask using the PDQ-5 code. (8) In this mockup, each fuel element, the aluminum fuel basket, the lead shield, etc., are separately represented as distinct regions. (Refer to Fig. 1.)

For all calculations which have involved symmetric groupings of similar fuel elements (e.g., 28 Core II elements), it has been possible to use a quarter-cask mockup. This mockup is represented as a $68 \times 54 \mathrm{PDQ}-5$ mesh. For the earlier calculations $(1)$ involving mixtures of different fuel types, a half-cask mockup has been used; this mockup is represented by a $43 \times 75$ mesh.

As previously stated, an infinite array of shipping casks has been considered in order to comply with 10 CFR 71. It has been assumed in the calculations that the shipping casks are arranged in a rectangular array and are touching at the outer points of their respective shields. The presence of cooling fins and other outer structures which would tend to increase the separation are neglected, since these could conceivably be damaged by some hypothetical accident. Water was assumed to be present in both the fuel element cavities and in the open spaces between the shipping casks.

Using the nuclear and spatial models outlined above, criticality calculations were performed as a function of the amount of cadmium in the fuel basket. The cadmium was assumed to be uniformly dispersed throughout the aluminum fuel basket. The effective multiplication factor for the cask array was calculated both with and without the assumption of axial leakage. In addition, the infinite multiplication factor was calculated for the fuel basket assembly alone. 
The multiplication factors were first determined for the zero cadmium condition with the following fuel loadings: 28 Core I spiked elements; 21 Core 1 regular and 7 Core I spiked elements; 28 Core II elements; and 28 Core I regular elements. The multiplication factors for the 28 spiked element and Core $1 /$ element cases were recalculated for the final analysis and those for the remaining two cases were obtained by utilizing the results of Ref. (1) and the more recent calculations. Further calculations were then made over a range of cadmium content from zero to one weight percent using 28 Core 1 spiked, nonborated (5.2 wt. \% U-235) elements in the fuel basket.

The results and a discussion of the calculations are given in the following discussions. 


\section{RESULTS}

The initial criticality calculations were made for an infinite array of shipping casks assuming no cadmium in the fuel basket and no axial leakage. The results for the various cask loadings of interest are given in Table 5-1.

\section{TABLE 5-1}

\section{MULTIPLICATION FACTOR OF INFINITE CASK ARRAY WITH NO CADMIUM IN FUEL BASKET}

cask loading

28 elements, 5.2 wt.\% U-235

21 elements, $4.3 w+. \%$ U-235

+7 elements, 5.2 wt.\% U-235

28 elements, 4.4 wt.\% U-235 . . . . . . . . 1.0483

28 elements, 4.3 wt.\% U-235 .......... . . 1.0418 infinite multiplication factor, $k_{\infty}$

It was found that the above values could be reduced by as much as 6 or $7 \% \triangle k$ if axial leakage is assumed.

The infinite multiplication factor for the fuel basket assembly alone was determined for the zero cadmium condition. The results are given in Table 5-2.

TABLE 5-2

INFINITE MULTIPLICATION FACTOR FOR FUEL BASKET ASSEMBLY WITH

NO CADMIUM IN FUEL BASKET

basket loading

infinite multiplication factor, $k_{\infty}$

28 elements, 5.2 wt.\% U-235 . . . . . . . . 1.2305

21 elements, $4.3 w+. \%$ U-235

+7 elements, 5.2 wt.\% U-235 . . . . . . . . . 1.1923

28 elements, 4.4 wt.\% U-235 . . . . . . . 1.1734

28 elements, 4.3 wt.\% U-235 . . . . . . . . 1.1663 
The final criticality calculations were made for the most reactive loading (28 elements, $5.2 \mathrm{wt} . \% \mathrm{U}-235)$ as a function of the cadmium content of the aluminum fuel basket. The multiplication factor of the infinite cask array is given first in Table 5-3.

TABLE 5-3

\section{MULTIPLICATION FACTOR OF INFINITE CASK ARRAY WITH \\ 28 ELEMENTS, 5.2 WT.\% U-235}

weight percent cadmium infinite multiplication factor, $k_{\infty}$

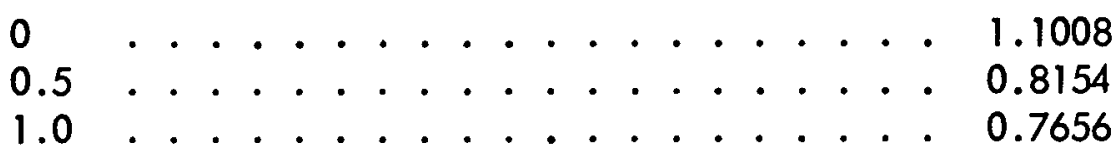

The infinite multiplication factor of the fuel basket assembly alone as a function of cadmium content is given in Table 5-4.

TABLE 5-4

INFINITE MULTIPLICATION FACTOR

FOR

FUEL BASKET CONTAINING 28 ELEMENTS, 5.2 WT.\% U-235

weight percent cadmium

infinite multiplication factor, $k_{\infty}$

$\begin{array}{llllllllllllllllllllll}0 & . & . & . & . & . & . & . & . & . & . & . & . & . & . & . & . & . & . & . & . & 1.2305 \\ 0.5 & . & . & . & . & . & . & . & . & . & . & . & . & . & . & . & . & . & . & . & . & 0.8867 \\ 1.0 & . & . & . & . & . & . & . & . & . & . & . & . & . & . & . & . & . & . & . & . & 0.8314\end{array}$ 


\section{DISCUSSION}

The zero cadmium results in Table 5-1 for an infinite array of shipping casks with a loading of 28 fresh Core I spiked elements and no boron in the cladding show that the array would be substantially supercritical even if axial leakage can be assumed. The second most reactive loading considered (21 Core I regular and 7 Core I spiked elements) is barely critical assuming axial leakage. The less reactive loadings would be critical if there is no axial leakage and subcritical if axial leakage is assumed. The requirements of 10 CFR 71 concerning an "unlimited number" of casks in "any arrangement" are interpreted to mean that no credit may be taken for axial leakage since shipping casks could presumably be stacked on top of one another. Therefore, axial leakage is neglected completely for the purposes of evaluating the required cadmium content even though the fuel element end fittings assure some spacing and, hence, neutron leakage between the uranium-bearing portions of the fuel elements.

The results shown in Table 5-2 give the infinite multiplication factor of the loaded fuel basket assembly without the cask portion. The purpose of determining this quantity is that it is virtually independent of assumptions regarding the spacing between casks and the "optimum interspersed hydrogenous moderation." Thus, for example, if the $k_{\infty}$ of the fuel basket assembly was less than 1.0, no amount or type of external moderation could render the cask critical.

The calculations of the infinite cask array for a varying cadmium content in the fuel basket shows (see Table 5-3) that $1.0 \mathrm{wt} . \%$ cadmium is sufficient to reduce the multiplication factor to less than 0.80 . However, to alleviate any concern about optimum moderation and at the same time to avoid any uncertainties concerning cask integrity after hypothetical accident conditions, it was decided to base the final evaluation on the infinite multiplication factor of the fuel basket assembly alone. By basing the evaluation on this quantity it is assured that the cask will more than meet the criticality requirements as long as the basic integrity of the inner basket and its fuel is maintained. The results of the calculations as given in Tables 5-3 and 5-4 are also shown in Fig. 4. These results show that 1.0 wt.\% cadmium is sufficient to reduce the infinite multiplication factor of the fuel basket assembly to less than 0.85 . 


\section{CONCLUSIONS}

Based on the calculational results and the conservative assumptions made during the analysis, it is concluded that $1.0 \mathrm{wt} . \%$ cadmium uniformly dispersed in the 28-element fuel basket is more than sufficient to meet the criticality requirements of 10 CFR 71 for any combination of fuel elements now available, and for any fuel presently envisioned for future use in the Elk River Reactor core. From Fig. 4 it is seen that a cadmium content in the fuel basket as low as 0.5 wt.\% would still be sufficient to hold the multiplication factor of the fuel basket below 0.90 . 
8. FIGURES

8-1 


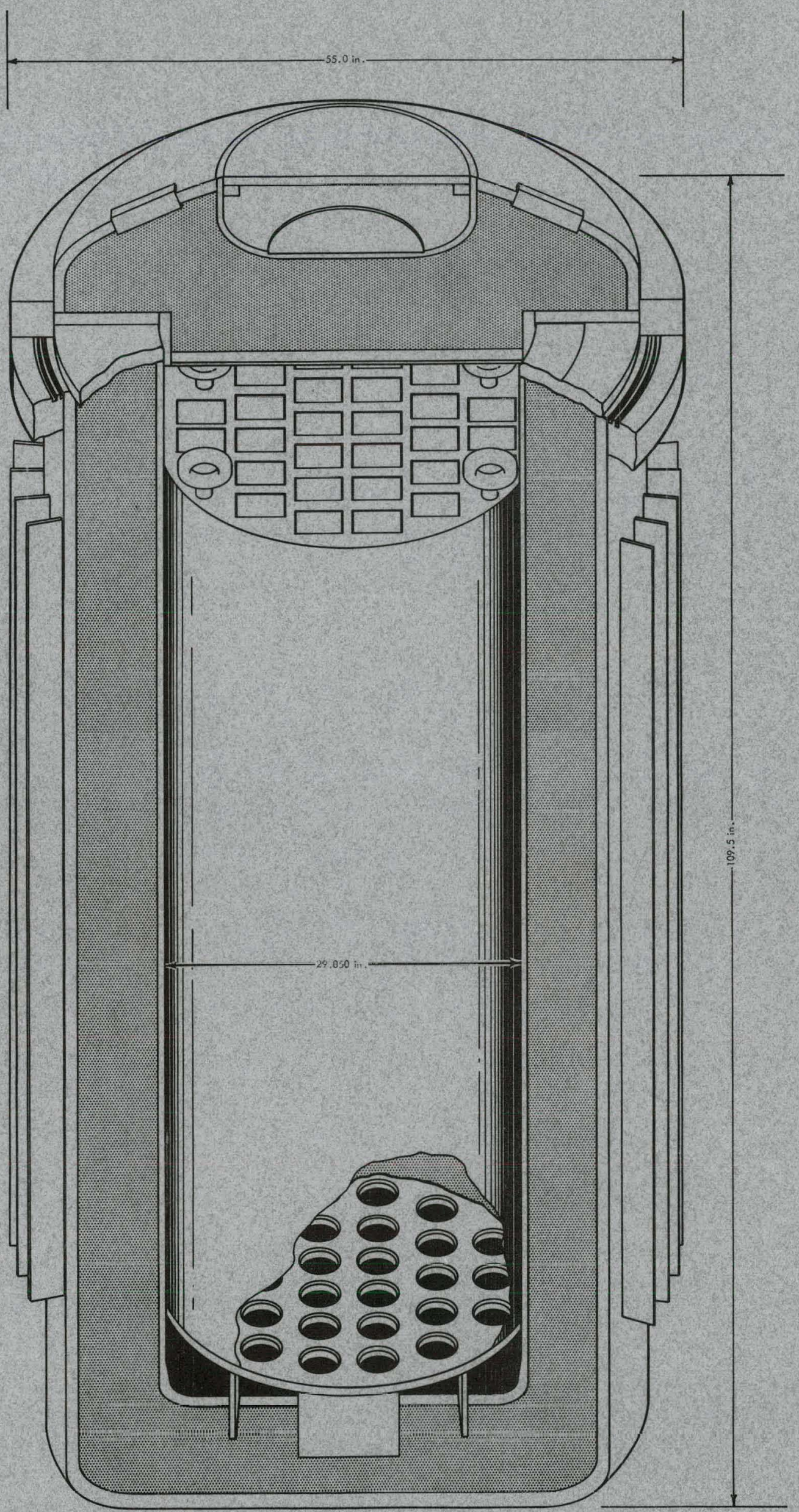




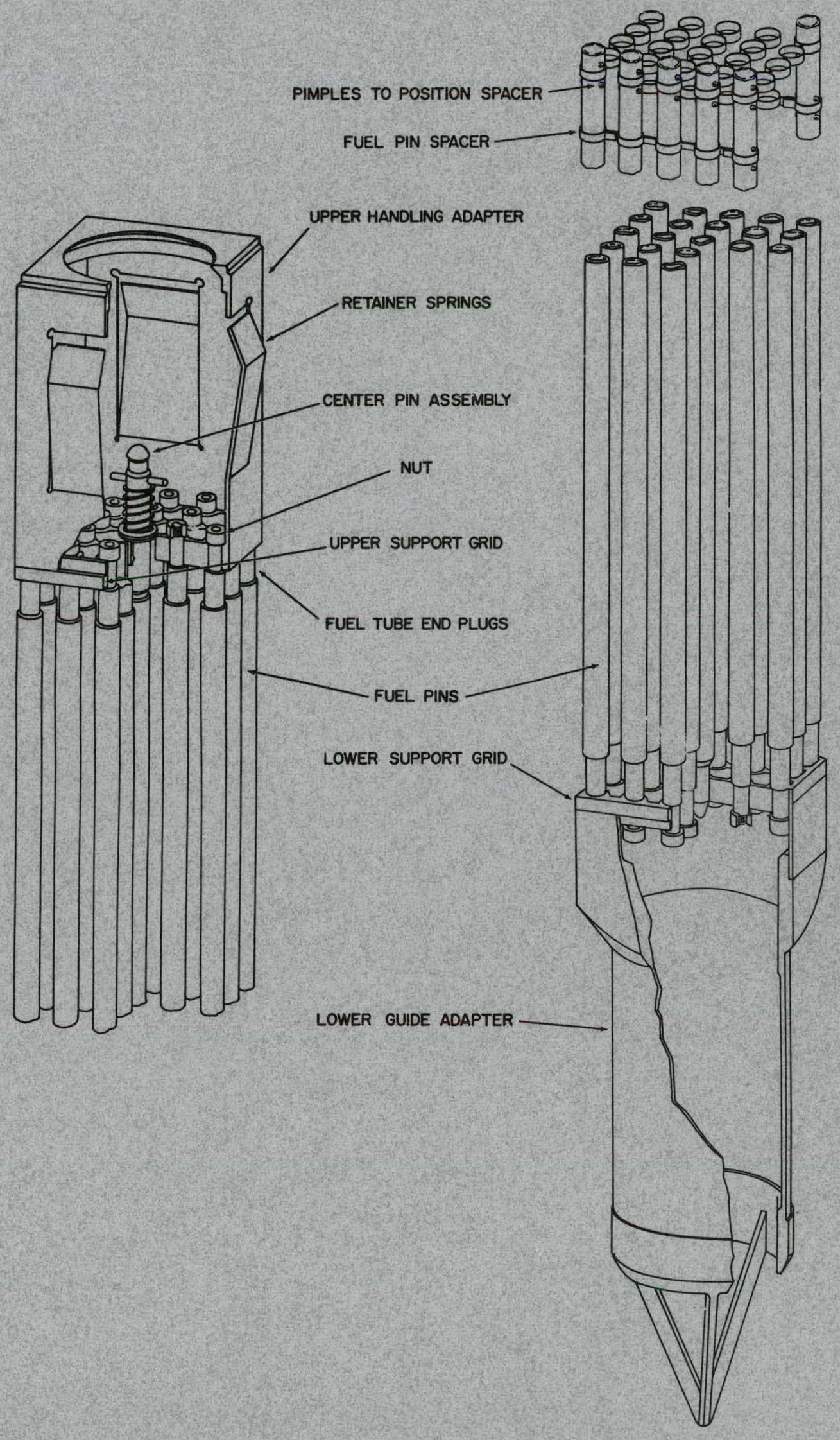

FIG 2 


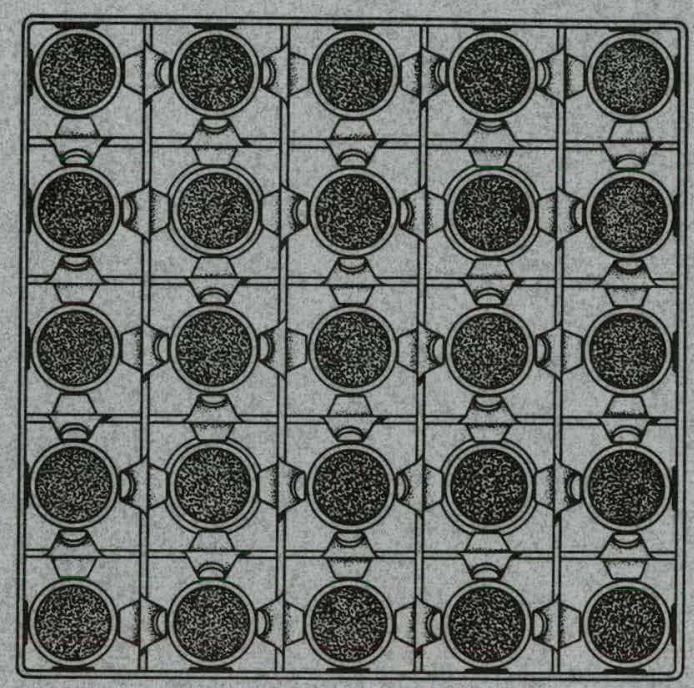

PLAN VIEW OF FUEL PIN SPACER ASSEMBLY

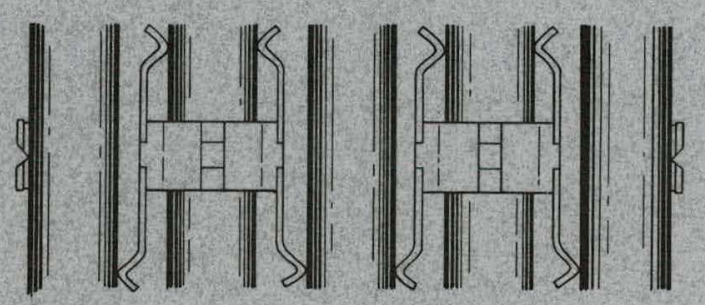

SECTION SHOWING COLLARS

\section{ERR \\ FUEL ELEMENT ASSEMBLY}

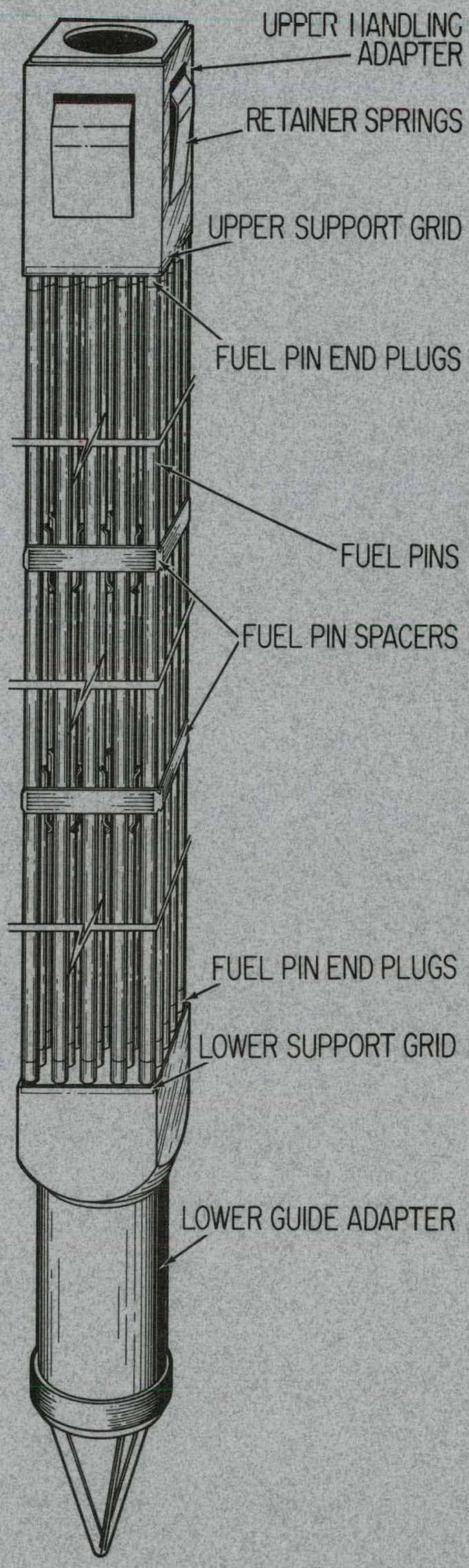

FIG 3 


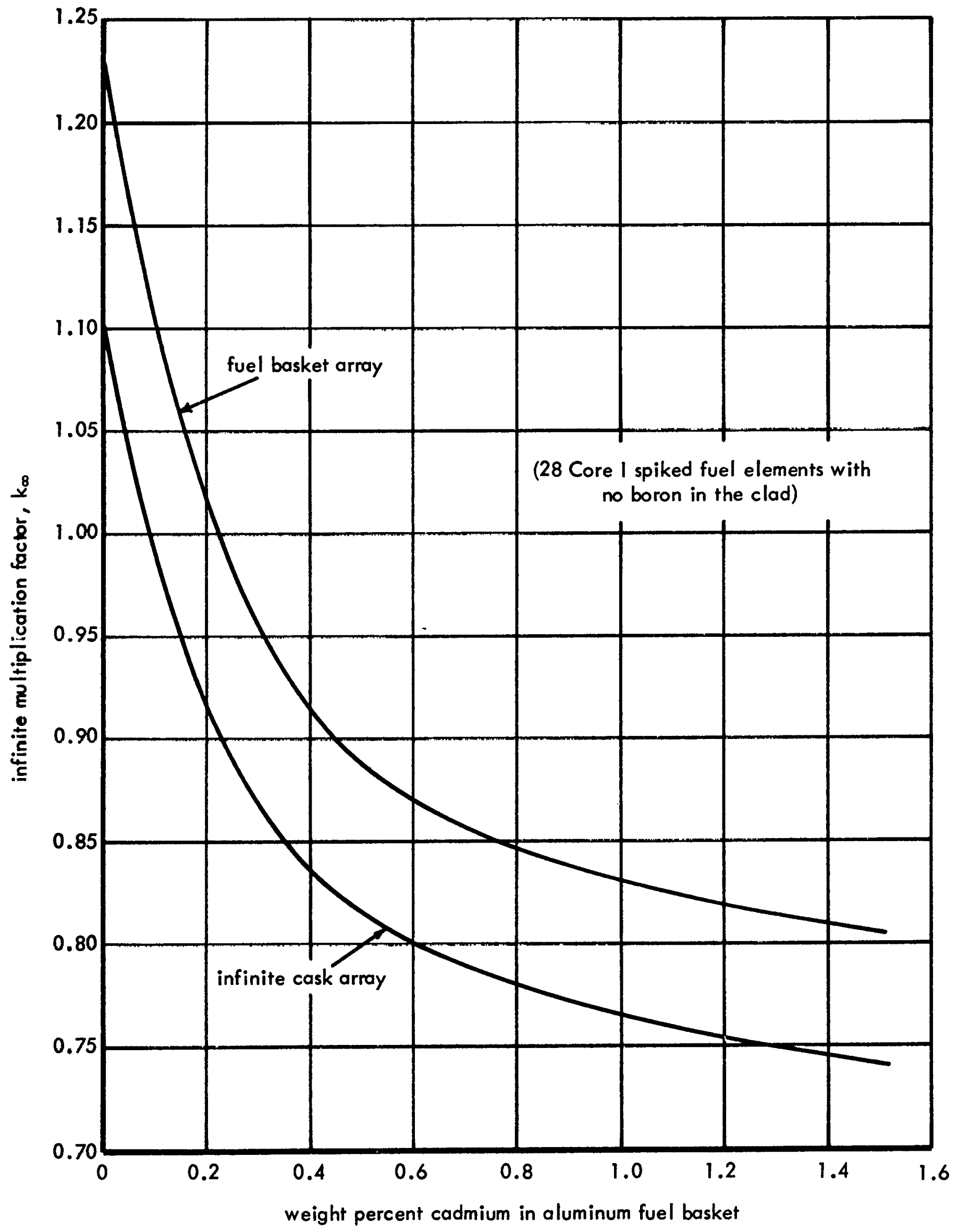

INFINITE MULTIPLICATION FACTOR VERSUS AMOUNT OF CADMIUM IN FUEL BASKET

FIG 4 


\section{REFERENCES}

1. Bond, G. R., Elk River Operations Analysis Program Criticality Analysis for the Elk River Reactor Shipping Cask, ACNP-63621, November 1963.

2. Knapp Mills Co. Drawings: F-2055 (Rev. 5), Cask Body Machining Details; F-2056 (Rev. 6), Closure Head Machining Details, June 1962.

3. Knapp Mills Co. Drawings: F-2279 (Rev. 0), Elk River Fuel Basket Final Machining (28 Element); F-2280 (Rev. 1), Elk River Fuel Basket Assembly (28 Element); and $\overline{\mathrm{C}-1727(\mathrm{Rev}}, 0)$, Elk River Fuel Basket Support Plate Fabrication and Machining, March 1964.

4. Westcott, C. H., Effective Cross Section Values for Well Moderated Reactor Spectra, CRRP-680, CRRP-787, CRRP-862.

5. Fisher, J.R., Effective Neutron Cross Sections for Thorium-Uranium Fuel Cycles, CNRN--A-C 500-2, August 1960.

6. Joanou, G. D., and Dudek, J. S., GAM-1, A Consistent P1 Multigroup Code for the Calculation of Fast Neutron Spectra and Multigroup Cross Sections, GA-1850, June 1961.

7. Shudde, R. H., and Dyer, J., TEMPEST-II, A Neutron Thermalization Code, AMTD111, May 1961.

8. Cadwell, W. R., et al, The PDQ-5 and PDQ-6 Programs for the Solution of the TwoDimensional Neutron Diffusion - Depletion Problem, WAPD-TM-477, January 1965. 